\title{
The challenges of project management in small and medium-sized enterprises: a literature review based on bibliometric software and content analysis
}

\author{
Os desafios da gestão de projetos em pequenas e médias \\ empresas: uma revisão de literatura apoiada em softwares de \\ bibliometria e análise de conteúdo
}

\author{
Letícia de Almeida Parizotto $^{1}$ (D), Aldo Tonso ${ }^{1}$ (D), Marly Monteiro de Carvalho² (D) \\ ${ }^{1}$ Universidade de São Paulo - USP, Escola Politécnica - POLI, Departamento de Engenharia Química, São Paulo, \\ SP, Brasil. E-mail: leticia.parizotto@usp.br; atonso@usp.br \\ 2Universidade de São Paulo - USP, Escola Politécnica - POLI, Departamento de Engenharia de Produção, São \\ Paulo, SP, Brasil, e-mail: marlymc@usp.br
}

How to cite: Parizotto, L. A., Tonso, A., \& Carvalho, M. M. (2020). The challenges of project

management in small and medium-sized enterprises: a literature review based on bibliometric software

and content analysis. Gestão \& Produção, 27(1), e3768. https://doi.org/10.1590/0104-530X3768-20

\begin{abstract}
The purpose of this paper is to design an overview about Project Management (PM) in Small and Medium-Sized Enterprises (SMEs) by analysing the evolution of publications and the main topics since 1996 to 2016 to motivate future research that helps SMEs to apply PM practices more efficiently. This study performed bibliometrics associated with content analysis of publications collected in scientific bases Web of Science and Scopus and in the periodic International Journal of Project Management. For that, the software VOSviewer, Nvivo, Minitab, and Excel were used in the analyses. The scan of 235 papers about Project Management in SMEs supported a literature overview. Furthermore, four thematic categories are highlighted: Project Management Practices, Planning and Control Systems, Collaboration, and Knowledge Management. Moreover, it was observed that SMEs requires a lighter PM methodology, focused on people and flexible. Besides that, the results show that the main challenges involve a lack of resources and qualified people and the high turnover. However, overcoming these issues, PM can benefit growth and innovation in SMEs. Therefore, this study presents a conceptual framework of benefits and challenges in Project Management in SMEs, reducing the research gap. Furthermore, recommendations for future research, mainly in Brazil, are given.
\end{abstract}

Keywords: Small and Medium-Sized Enterprise; SMEs; Project management; Bibliometry.

Resumo: $O$ objetivo deste artigo é elaborar um panorama da literatura sobre Gestão de Projetos (GP) em Pequenas e Médias Empresas (PMEs) através da análise da evolução das publicações e principais temáticas entre 1996 e 2016 para motivar futuras pesquisas que auxiliem PMEs a usarem práticas de Gestão de Projetos de forma mais eficiente. O estudo foi conduzido por bibliometria associada à análise de conteúdo das publicações coletadas nas bases Web of Science e Scopus e no periódico International Journal of Project Management. Para tanto, os softwares VOSviewer, Nvivo, Minitab e Excel foram utilizados nas análises. A varredura de 235

Received Jan. 30, 2017 - Accepted May 27, 2018

Financial support: Coordination for the Improvement of Higher Education Personnel (No. 1626676) and the São Paulo Research Foundation (FAPESP, Grant No. 2017/25065-9).

(c) (i) This is an Open Access article distributed under the terms of the Creative Commons Attribution License, which permits unrestricted use, distribution, and reproduction in any medium, provided the original work is properly cited. 
publicações sobre Gestão de Projetos em PMEs permitiu traçar um panorama da literatura. Ademais, quatro categorias temáticas se destacaram: Práticas de Gestão de Projeto, Sistemas de Planejamento e Controle, Colaboração e Gestão de Conhecimento. Como características da gestão de projetos em PMEs, observa-se a necessidade de uma metodologia mais leve, flexível e orientada a pessoas. Adicionalmente, os resultados apontam que os principais desafios envolvem a falta de recursos e pessoal qualificado, além da alta rotatividade. Entretanto, superando essas questões, a GP pode beneficiar o crescimento e a inovação em PMEs. Portanto, o estudo apresenta um quadro conceitual de benefícios e desafios da gestão de projetos em PMEs, reduzindo a lacuna de pesquisa no tema. Além disso, são apresentadas recomendações para pesquisas futuras, principalmente no Brasil.

Palavras-chave: Pequenas e Médias Empresas; PMEs; Gestão de projetos; Bibliometria.

\section{Introduction}

Small and medium-sized enterprises (SMEs) perform an important role in economic and social development. While in the European Union as well as the average member countries of the Organization for Economic Co-operation and Development (OECD), small and medium-sized enterprises represent more than $90 \%$ of establishments and contribute more than $60 \%$ of total turnover (Muller et al., 2015). In Brazil, however, they represent more than $98 \%$ of the companies and contributed only $27 \%$ of GDP in 2011 (SEBRAE, 2014). For Feldmann (2011), the lack of innovation, entrepreneurship training, and cooperation between companies are the main responsible for this low performance.

The contribution of SMEs is not limited to the large number of companies, employees, and share of GDP, moreover, they are also responsible for innovation (Mannan et al., 2016). SMEs have a great innovative capacity, however, the lack of resources and knowledge hamper their development (Marcelino-Sádaba et al., 2014). Therefore, there is a need to accelerate the growth and competitiveness of these enterprises (Forsman, 2008) for the progress of the economy (Mannan et al., 2016).

The study by Pollack \& Adler (2016) demonstrates that project management (PM) improves the financial performance of SMEs. In addition, Turner et al. (2010) confirms that it can benefit operations, growth and innovation processes of SMEs. However, there are obstacles in adopting traditional project management guides (such as PMBoK and IPMA ICB) because they are bureaucratic and have little focus on personal skills (Turner et al., 2009, 2010, 2012). In addition, SMEs have unique characteristics, such as limited human and financial resources, few clients, non-specialized employees, and high turnover (Forsman, 2008; Wong, 2005).

Despite their collaboration with the global economy and the key role in the development of nations, few publications about project management in SMEs are available (Juca et al., 2010; Pollack \& Adler, 2016; Turner et al., 2010), and, according to Turner et al. (2012), for the PMI (Project Management Institute) interests SME-focused studies. To contribute to the literature, this article seeks to answer the following research question (RQ): What are the challenges and benefits of project management for SMEs?

Facing this context, this study aims to outline the project management landscape in SMEs from 1996 to 2016, identifying the main topics, references and trends, through bibliometric analysis and content according to literature methodologies (Carvalho et al., 2013a; Iritani et al., 2015; Watanuki et al., 2014). In this way, aiming to contribute to 
the construction of the knowledge of the area and with future research focused mainly on how project management can benefit SMEs.

The article follows this structure: section 2 presents the most relevant characteristics of SMEs and the main challenges. Section 3 explains the Research Methodology based on data of ISI Web of Science, Scopus and the International Journal of Project Management, on their statistical analyses (evolution of publications per year, main journals, and countries) and on bibliometrics (networks of keywords, co-citation, identification of outliers and hot topics). For this purpose, VOSviewer software (van Eck \& Waltman, 2010), Nvivo (QSR International Pty Ltd., 2012) and Minitab (2010) are used. Section 4 shows the results of the previous analyses. Next, section 5 presents the content analysis of the main publications, and section 6 discloses the discussion. Finally, section 7 develops the conclusions, recommendations, and limitations.

\section{SMEs: profile and main challenges}

Different countries use diverse classifications of company sizes (OECD, 2016), as shown in Table 1. These divergences hamper the study of this area, so the commonly adopted classification is based on the number of employees (OECD, 2016), as in this study. The economic sector of SMEs also depends on the country. Among OECD members, SMEs are the majority of the construction and service sectors (OECD, 2016). The same report indicates that services and manufacturing predominate over construction in Brazil. In the European Union, the companies of service-related sectors are growing (Muller et al., 2015). In addition, the financial performance is also divergent, while the average OECD membership is $60 \%$ of the total economic value added; in Brazil, it is less than 50\%; and, in Japan, it is practically $100 \%$ (OECD, 2016).

Table 1. Different SMEs Classification Systems.

\begin{tabular}{cccc}
\hline Classification & Micro Enterprise & Small Enterprise & Medium Enterprise \\
\hline $\begin{array}{c}\text { OECD } \\
\text { (OECD, 2016) }\end{array}$ & $1-9$ employees & $10-49$ employees & 50-249 employees \\
\hline $\begin{array}{c}\text { European Commission } \\
\text { (Muller et al., 2015; }\end{array}$ & $\begin{array}{c}1-9 \text { employees } \\
\text { Turner et al., 2009) }\end{array}$ & $\begin{array}{c}10-49 \text { employees } \\
\text { GR }<€ 10 \text { millions }\end{array}$ & $\begin{array}{c}50-249 \text { employees } \\
\text { GR }<€ 50 \text { millions }\end{array}$ \\
$\begin{array}{c}\text { National Statute of } \\
\text { Microenterprise and } \\
\text { Small Business (Brasil, } \\
\text { 2006) }\end{array}$ & GR $<\mathrm{R} \$ 0.36$ millions & $\begin{array}{c}\text { GR }<\mathrm{R} \$ 4.8 \\
\text { millions }\end{array}$ & N/A $^{* *}$ \\
\hline
\end{tabular}

*GR: Gross Revenue; **N/A: not applicable. Complementary Law 123/2006 (Brasil, 2006) does not address medium-sized enterprises.

Despite these differences, SMEs have characteristics in common. In general, they have a small number of employees led by a visionary entrepreneur (Juca et al., 2010) or by founding partners, who also holds senior management roles, which means there are few hierarchical levels (Huin, 2004). Therefore, there is a close relationship between top-management and employees that provides informal communication (Huin, 2004; Malhotra \& Temponi, 2010). In addition, employees perform various tasks (Malhotra \& Temponi, 2010) and need multiple skills (Forsman, 2008) and there is no clear and formal division between departments (Huin, 2004). Moreover, SMEs do not 
usually have a product portfolio, hence they specialize in a niche market (Malhotra \& Temponi, 2010).

SMEs need to address several challenges to become more competitive and to enter the market. Globalization, rapid advances in technology, and shortening product lifecycle force SMEs to be more innovative (Mannan et al., 2016). However, government difficulties and access to funding may hinder this process (OECD, 2016; Mannan et al., 2016). Another challenge is to hire qualified employees (Malhotra \& Temponi, 2010), as the lack of necessary skills and human resistance to change are obstacles to innovation (Mannan et al., 2016). SMEs have lower intellectual capital than large companies (Hsu \& Fang, 2009). Moreover, SMEs are not able to manage innovation in a systemic way, resulting in indefinite and flawed projects (Marcelino Sádaba et al., 2016).

\section{Research methods}

Given the characteristics of the objectives and research, the methodology is a systematic literature review (Carvalho et al., 2013a). The systematic review of the literature is built on a clear question whose answer is developed based on a reproducible scientific method that determines rigorous criteria for information evaluation. Because it is broad, the systematic review can synthesize important concepts from a certain field of knowledge. Thus, indicating trends for future research and providing researchers with a concise overview of the area. The systematic review employs several tools, among them, bibliometry, content analysis and semantics (Carvalho et al., 2013a; Sampaio \& Mancini, 2007). For this work, we selected bibliometrics and content analysis.

\subsection{Sampling process}

The sample was collected from ISI Web of Science (2016) and Scopus (2016) databases, since they are bases that include publications from other databases and allow the extraction of metadata (abstracts, references, number of citations, institutions, among others) that support the bibliometric study (Carvalho et al., 2013a; Iritani et al., 2015; Watanuki et al., 2014). In addition, the ISI Web of Science presents only papers published in journals with impact-factor (IF) calculated in the Journal Citation Report (JCR) (Carvalho et al., 2013a). Additionally, publications of the International Journal of Project Management (IJPM, 2016) were included due to the importance of this journal. The strings were "project management" and "small company or medium companion or small enterpris * or medium enterpris * or sme", the publications were filtered by year (1996 to 2016) and by type (article, review, and article in press).

This process resulted in 408 identified publications. Of this sample, 33 publications were excluded because they were repeated and 140 because they did not approach Project Management in SMEs after reviewing titles, abstracts, and keywords. Most of the excluded were in the knowledge area, but not specifically for SMEs or were studies about large companies and SMEs. In these cases, an individual evaluation was executed to exclude only those whose main sample was composed of large companies and not SMEs. For example, Proverbs et al. (1999) presents the term SME only as a reference because the entire study was performed with projects of large companies in 
the construction sector. Hence, bibliometric and content analyses were performed as shown in Figure 1.

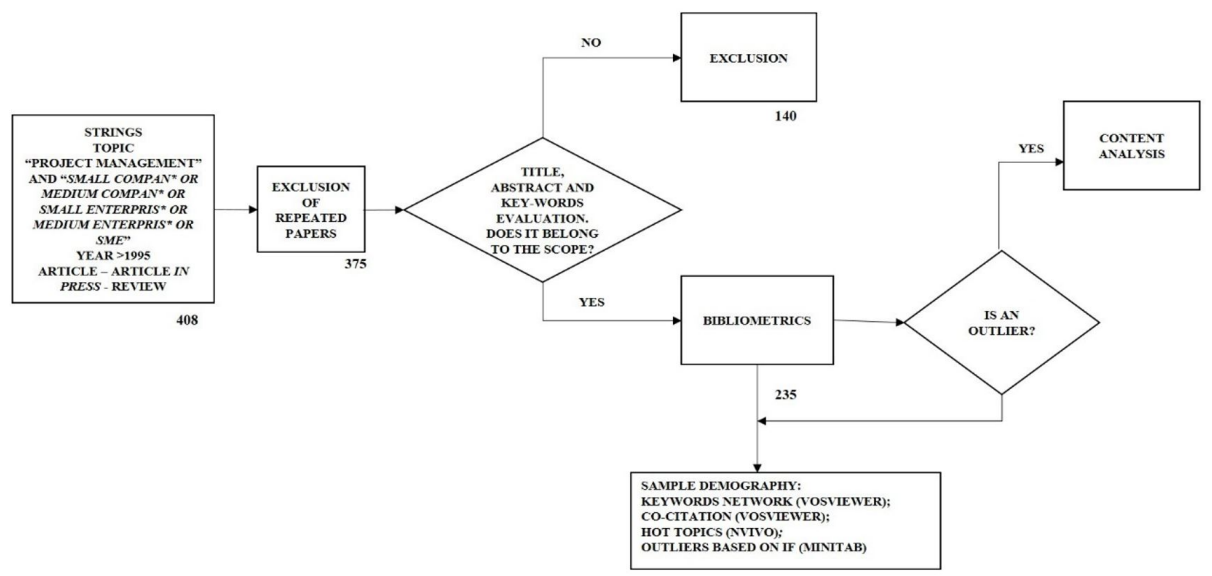

Figure 1. Flowchart that represents the Research Method.

\subsection{Data analysis}

Bibliometry was conducted in two steps: metadata and content analyses. The first study, called Sample Demography, consisted of three stages: counting the number of publications per periodical per year, which identified the journals that generally approach the theme (Carvalho et al., 2013a); count of the total of publications per year, that delineated the evolution of the area; and stratification by country, which indicated the countries that contributed most to the construction of the area.

The second analysis was based on bibliometric networks of the metadata using VOSviewer (van Eck \& Waltman, 2010). The first network was that of keywords, which established the terms that occur concomitantly. In this study were excluded similar terms (e.g. "erp", that means Enterprise Resource Planning); the second was that of co-citation, which demonstrated the degree of similarity between articles that are cited together (Carvalho et al., 2013a).

Nvivo software (Bazeley \& Jackson, 2013) was used in content analysis and identification of hot topics. The hot topics indicate interesting topics in the area of knowledge, according to the methodology proposed by Banks (2006). In general terms, the calculated $m$-index, which results from the ratio of citations per author per year, indicates whether the topic is of wide scope and importance $(m>2)$, or has the potential to become a hot topic $(0.5<m<2)$, or if it is of restricted interest $(m<0.5)$.

Outliers are papers with high performance of the impact factor (IF), which results of the relation between number of citations per year $\left(C_{n}\right)$ and the impact factor of the journal according to the JCR (JIF), as Equation 1 demonstrates (Carvalho et al., 2013a). This statistical analysis was conducted in Minitab software. Articles without citations were excluded. Finally, the second stage relied on content analysis of these outliers and other relevant papers to identify the main topics addressed and the main challenges involved in SMEs' projects (Carvalho et al., 2013b). 
$I F=C_{n} x\left(1+J_{I F}\right)$

\section{Results}

\subsection{Sample demography}

The 235 valid publications belonged to 137 journals from various areas such as engineering, business, administration, computer science, environmental sciences, decision science, among many others. Therefore, the theme was relevant and multidisciplinary. Of the total periodicals, approximately $70 \%$ had only one publication. Almost $20 \%$ of the publications were concentrated in 4 journals, namely International Journal of Project Management (30), ZWF (8), Production Planning and Control (7), and Construction Management and Economics (7). Regarding the publications of these 4 journals, as is shown in Figure 2, the first one was published in 2001, and it is interesting to note that only the IJPM showed an increasing trend in the number of publications. Reminding that the sample was withdrawn in September 2016, thus this number may have increased.

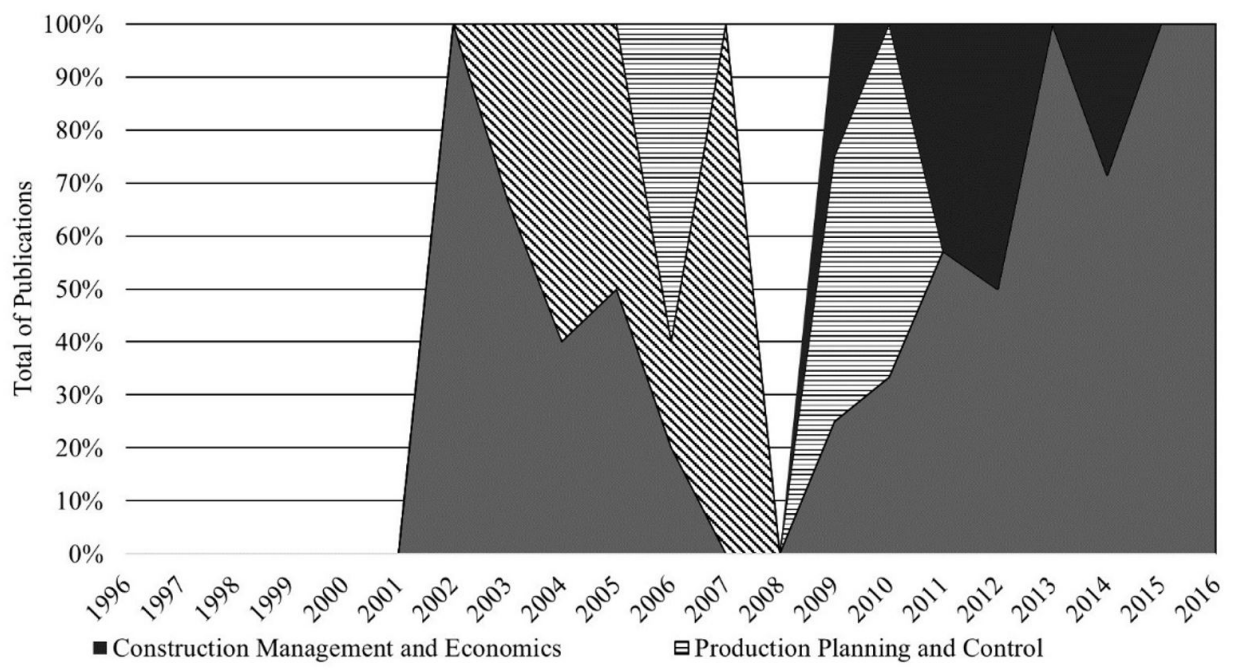

వZWF Zeitschrift fuer Wirtschaftlichen Fabrikbetrieb $\square$ International Journal of Project Management

Figure 2. Profile of publications along the years 1996 and 2016 by the principal journals. Source: Web of Science (2016), Scopus (2016) and IJPM (2016).

The analysis of publications, Figure 3, per year revealed that, on average, journals accepted 12 publications per year and there was a peak with 26 publications in 2010 . About half the sample came from six countries: the United Kingdom (17\%), Germany $(10 \%)$, the United States (7\%), Taiwan (5\%), Spain (5\%) and India (4\%), as is shown in Figure 4. The prominence of European nations was due to the most European companies are SMEs, therefore the development of these countries depends on their growth and innovation (Marcelino Sádaba et al., 2016). In relation to Brazil, only 4 publications were found, although $98 \%$ of their companies are SMEs, demonstrating that there is space for research in the area. 


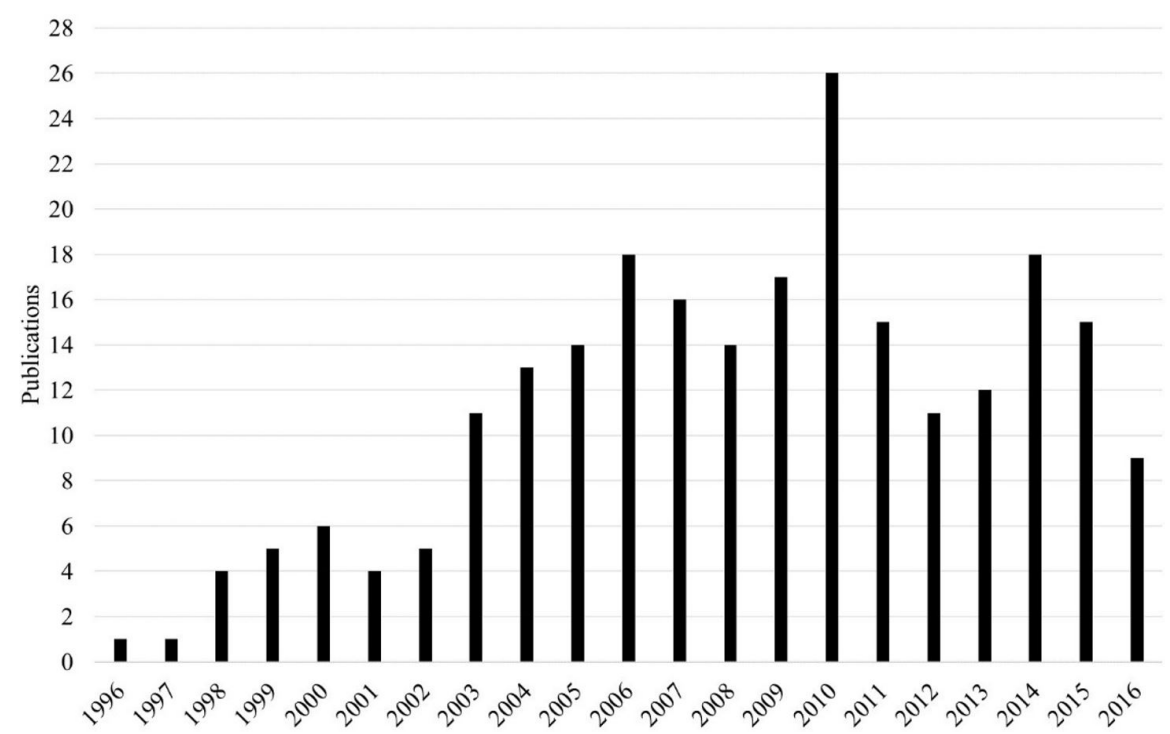

Figure 3. Profile of publications along the years 1996 and 2016. Source: Source: Web of Science (2016), Scopus (2016) and IJPM (2016).

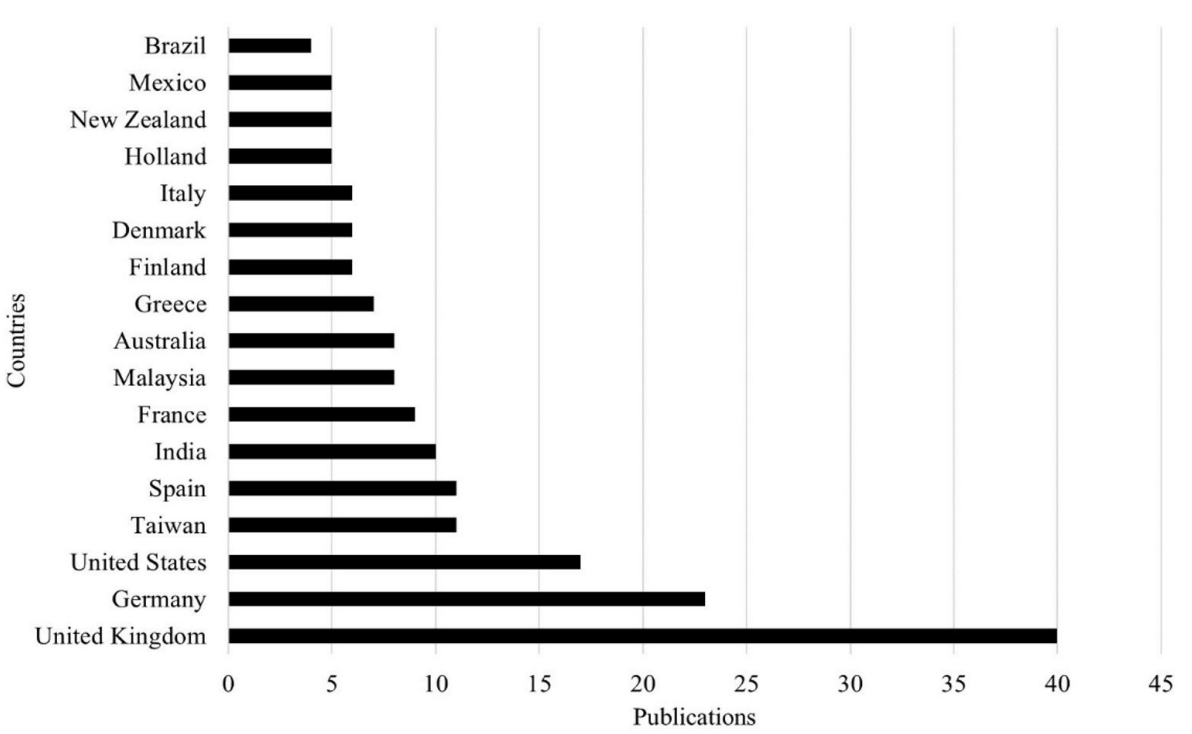

Figure 4. Countries with the highest number of publications. Brazil ranked at $17^{\text {th }}$. Source: Web of Science (2016), Scopus (2016) and IJPM (2016).

\subsection{Main themes}

Figure 5 shows the keyword network designed in VOSviewer software, selecting keywords with at least 6 occurrences. The position reveals the proximity between the terms; and the lines, concomitant occurrences. Project management was the main theme that interconnects the others. Three major topics were: Manufacturing, Construction and Information, Innovation and Knowledge. Table 2 shows these categories. 


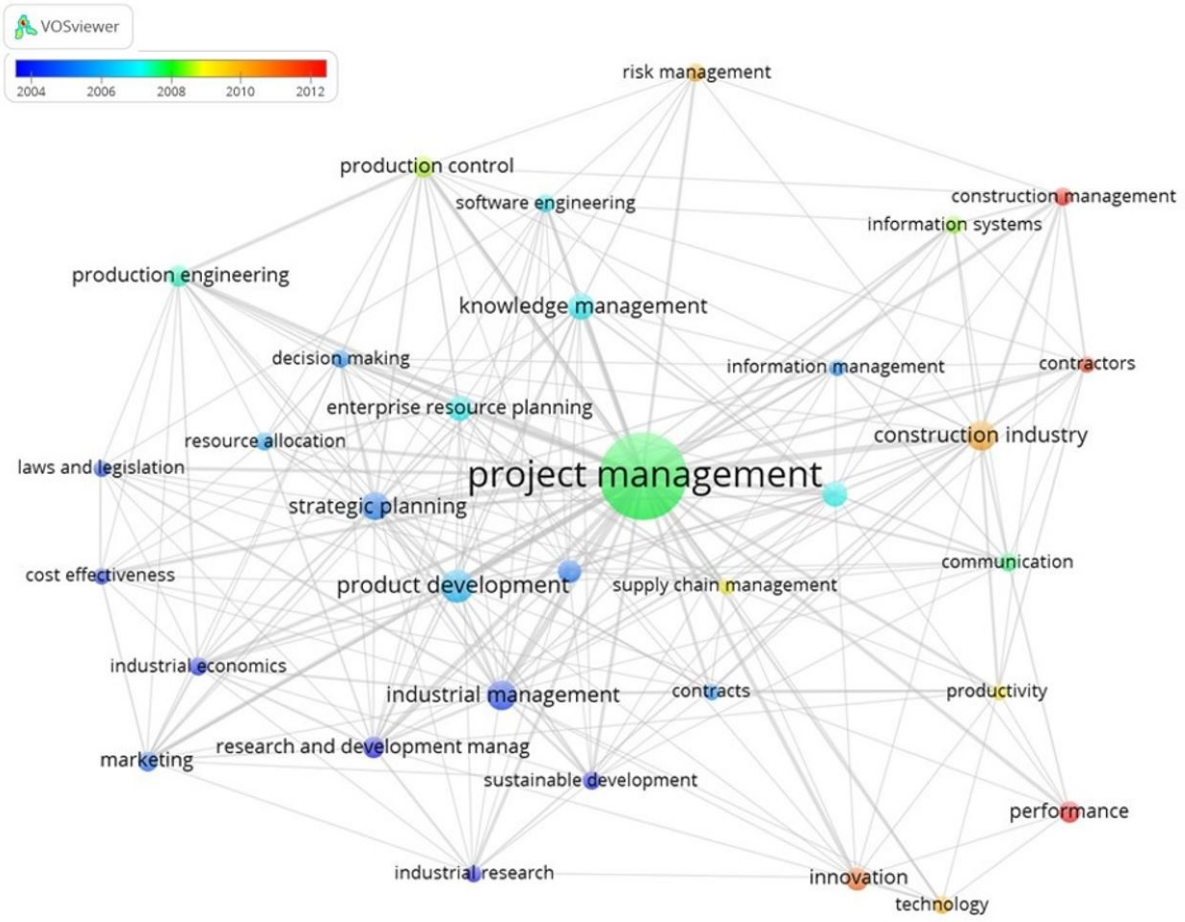

Figure 5. Keywords Network classified by year, there were selected keywords with, at least, six occurrences. Source: Web of Science (2016), Scopus (2016) and IJPM (2016).

Table 2. Theme classification of keywords by affinity. This classification was performed by VOSviewer.

\begin{tabular}{cc}
\hline Theme & Keywords \\
\hline Manufacturing & $\begin{array}{c}\text { Industrial, management, strategic, product development, industrial } \\
\text { economics, marketing, sustainable development, laws and legislation, cost } \\
\text { effectiveness, production control, production engineering, enterprise } \\
\text { resource planning, supply chain management, decision making, resource } \\
\text { allocation }\end{array}$ \\
\hline $\begin{array}{c}\text { Construction \& } \\
\text { Information }\end{array}$ & $\begin{array}{c}\text { Information management, construction industry, information technology, } \\
\text { communication, information systems, construction management, } \\
\text { contractors, contracts }\end{array}$ \\
\hline $\begin{array}{c}\text { Innovation \& } \\
\text { Knowledge }\end{array}$ & $\begin{array}{c}\text { Innovation, performance, project management, productivity, technology, } \\
\text { research and development management, societies and institutions, } \\
\text { industrial research, knowledge management, software engineering, risk } \\
\text { management }\end{array}$ \\
\hline
\end{tabular}

The first theme, Manufacturing, embedded in the SME research because of the pressure they underwent to meet the needs of large customers and become globally competitive (Huin, 2004; Malhotra \& Temponi, 2010). Examples of topics were: the implementation of advanced manufacturing technologies in SMEs (Dangayach \& Deshmukh, 2005); the application of the ERP system (Huin, 2004; Malhotra \& Temponi, 2010; Mohammadjafari et al., 2011; Muscatello et al., 2003; Zafeiropoulos et al., 2005); and the development of information system for mass customization (Dean et al., 2009).

Regarding the second theme, Construction \& Information, approximately, $10 \%$ of the sample addressed it. One of the most cited articles in the sample (127 citations), by Sage et al. (2010), states that construction sector SMEs should adopt supply chain 
practices to become more reliable and productive. Another relevant article (51 citations), by the Sexton \& Barrett (2004), presents a model to help construction SMEs to improve technology management to become more competitive. Implementing information systems was widely approached as a means to control, integrate and manage chains of small and medium-sized contractors (Ahuja et al., 2009a; Jacobsson \& Linderoth., 2012; Lee \& Egbu, 2007; Lin, 2010; Pellicer et al., 2009).

About the third theme, it was assumed that innovation depends on knowledge management. There were researches that focused on developing specific methodologies for SMEs, such as innovation management (Maravelakis et al., 2006), risk management (Marcelino-Sádaba et al., 2014), and management of innovation portfolio (Von Ahsen \& Heesen, 2009). Other studies addressed public policies to support innovation in SMEs (Egbetokun et al., 2009; Hwang \& Ward, 2001). In addition, some researchers studied innovation projects between SMEs and research institutions (Bjerregaard, 2010; Davenport et al., 1998; Okamuro, 2007).

The analysis of hot topics identifies topics within a research area that are interesting to the scientific community (Banks, 2006). In Figure 6, it can be seen from the m-index that there were no hot topics, however, there were topics likely to become hot topics in a larger scientific community $(0.5<\mathrm{m} \leq 2)$ (Banks, 2006), they were: Processes, Information, Technology, Development, Products, and Success. The trend was confirmed in 6 of the 9 articles published in 2016, as is shown in Table 3. On the other hand, Software, Business, Construction, Knowledge, and Tools were topics of interest to a smaller scientific community ( $m<0.5)$ and were not hot topics (Banks, 2006).

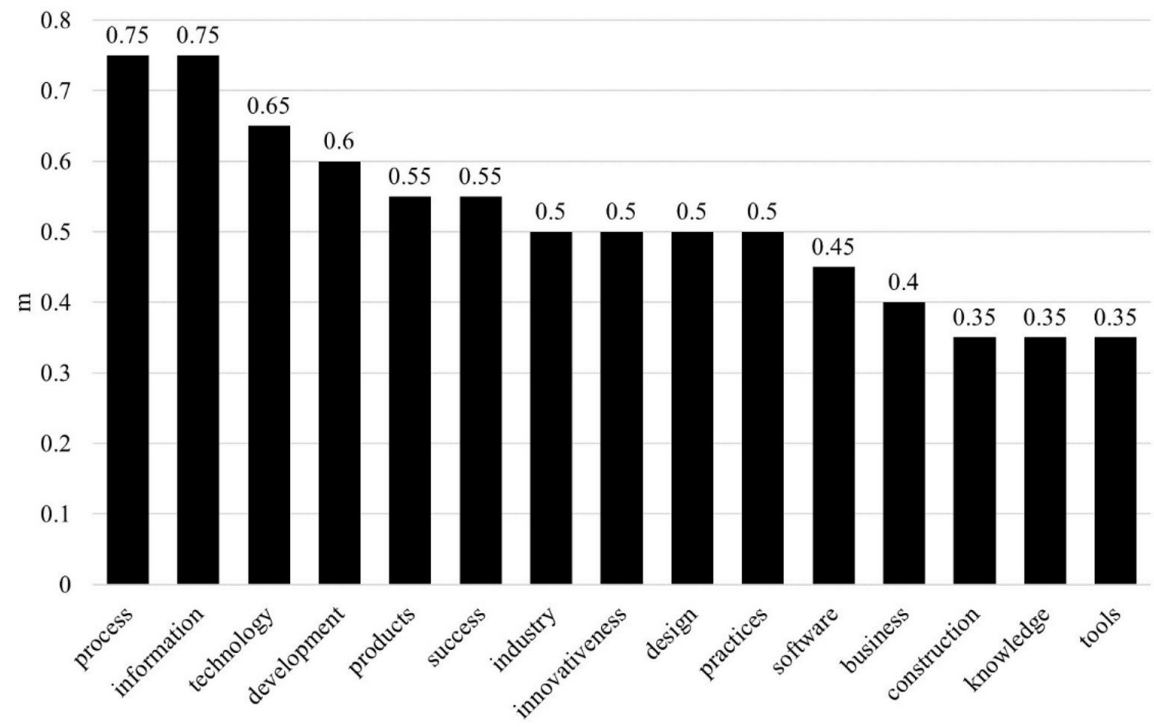

Figure 6. The m-index of the main topics. Index over 2 indicates hot topics; between 0.5 and 2 , likely hot topics; and bellow 0.5 , not hot topics. 
Table 3. Relationship between the likely hot topics and published papers in 2016.

\begin{tabular}{cc}
\hline Hot Topics & Articles \\
\hline Success \& Process & (Moreau, 2016) \\
\hline Success & (Marcelino Sádaba et al., 2016) \\
& (Pons \& Haefele, 2016) \\
\hline Success, Information \& Technology & (Pollack \& Adler, 2016) \\
Technology \& Information & (Mannan et al., 2016) \\
\hline
\end{tabular}

Among the published articles in 2016, the topic of success was presented in combination with processes and information technology. For example, according to Marcelino Sádaba et al. (2016) and Moreau (2016), the implementation of appropriate project management for SMEs is a critical success factor for the company's survival. Another success factor is the effective teamwork (Pons \& Haefele, 2016). Regarding IT, Pollack and Adler cite "[...] using project management and IT professional skills to undertake core business activities make a significant contribution to improving the financial performance of small to medium enterprises." (Pollack \& Adler, 2016, p. 836). Therefore, for researchers of SMEs, studies combining these topics are of interest to the scientific community. In addition, they are themes that are of interest to project management practitioners in SMEs, as they relate to the competitiveness and survival of these companies.

\subsection{Outliers - main authors and studies}

"While in many fields outliers can simply be discarded as being exceptions, in bibliometrics the extreme values represent the high-end of research performance and therefore deserve special attention", says Glänzel (2013, p. 13). In Figure 7, there are 17 outliers publications that cover mainly four themes: Project Management Practices, Control and Planning Systems, Collaboration, and Knowledge Management, which were discussed in the next session.

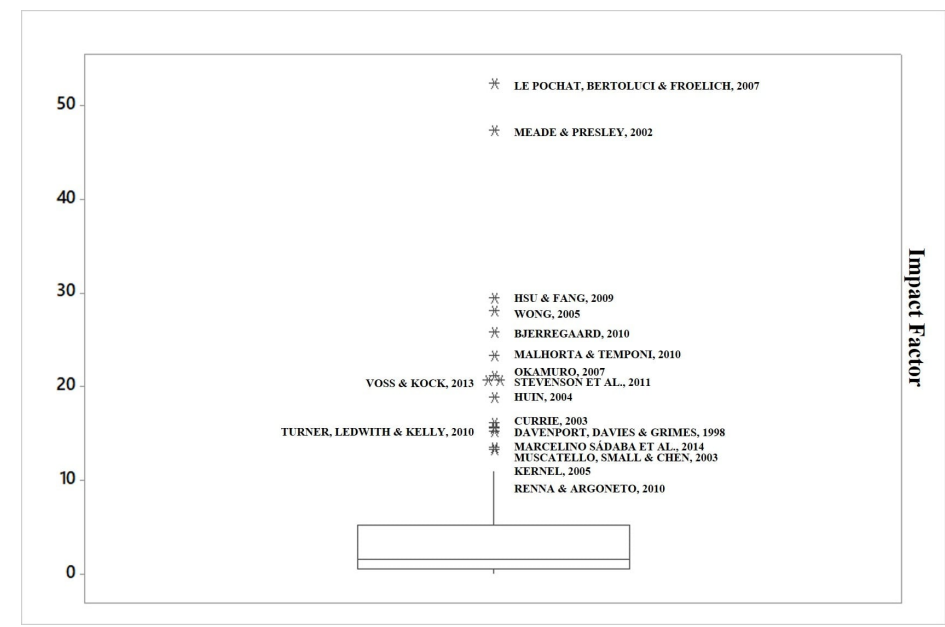

Figure 7. Outliers according to the Impact Factor value designed by Minitab. Source: Web of Science (2016), Scopus (2016) and IJPM (2016). 
Figure 8 shows the citations of these outliers articles between 1996 and 2016 . These 17 publications received altogether $47 \%$ of the total citations. The first was in 2001, the article by Davenport et al. (1998) on collaborative research between SMEs and research institutes. The citations practically tripled between 2006 and 2011. Subsequently, they stabilized between 2011 and 2016. Interesting, Wong's (2005) study about the knowledge management in SMEs received $51 \%$ of outliers' citations.

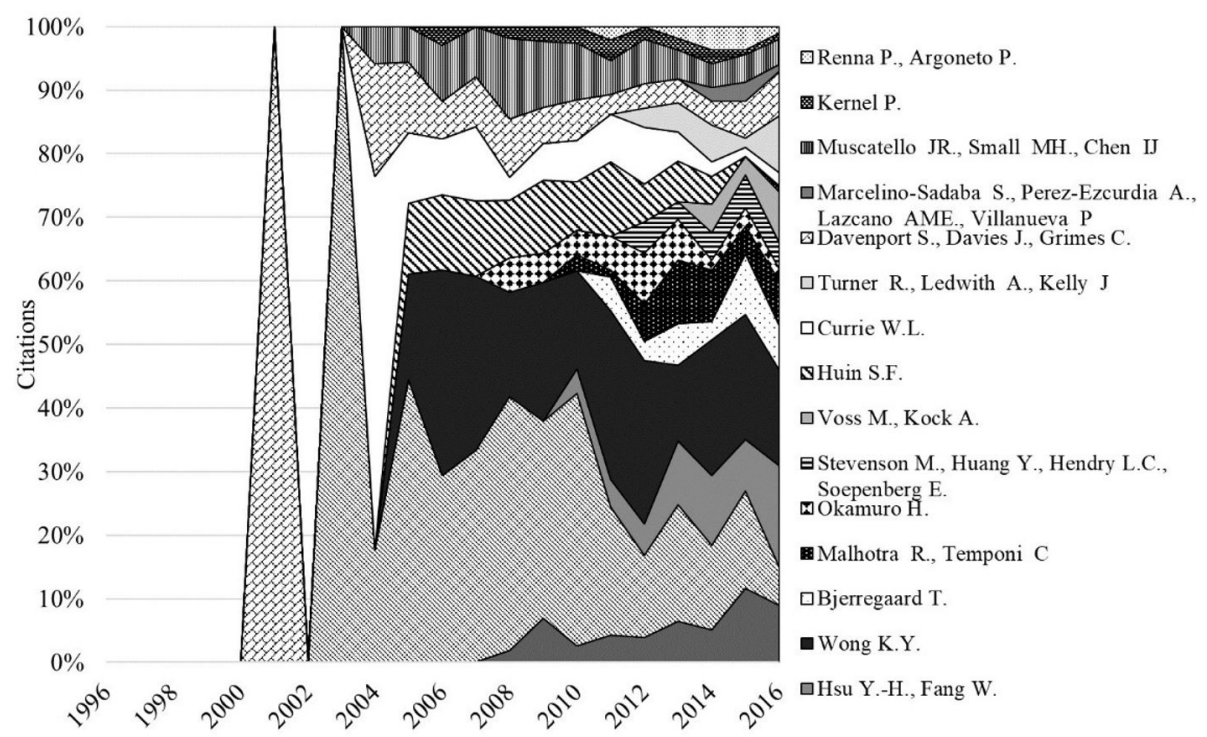

Figure 8. Percentage of citations of outliers along the years 1996 and 2016. Source: Web of Science (2016), Scopus (2016) and IJPM (2016).

The researches that have gained prominence in the last five years were: Turner et al. (2010) studied the use of project management practices in SMEs; Le Pochat et al. (2007) analysed ecodesign tools; Voss \& Kock (2013) approached the influence of marketing on portfolio management; Hsu \& Fang (2009) investigated the knowledge management and development of new products; and Malhotra \& Temponi (2010) identified the best practices for ERP implementation in SMEs.

The 17 outliers applied different methodologies, 8 were qualitative studies (semi-structured interviews, case study), 4 used qualitative and quantitative methods (literature review and research), 4 were exclusively quantitative (research) and only 1 performed a simulation. The predominance of qualitative studies revealed that it is a developing area (Fleury et al., 2016).

The co-citation network, Figure 9, shows the most cited references in the sample. This network represents the frequency that two documents were cited together (Small, 1973). Table 4 summarizes the main themes of the clusters. The criterion for selection of publications was a minimum of 7 times citation. 


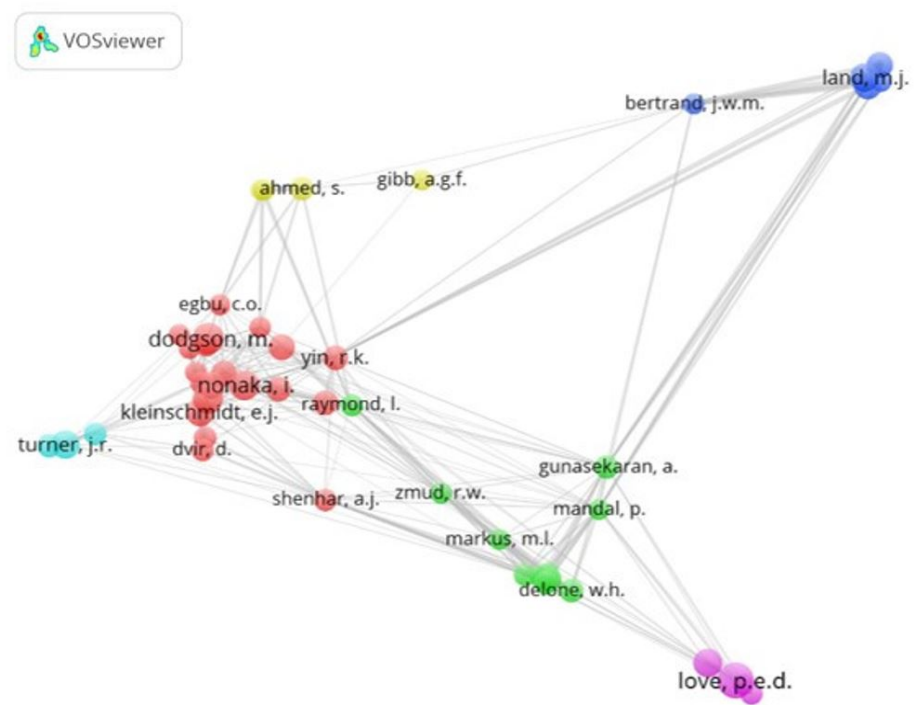

Figure 9. Co-citation network of the authors that were, at least, seven times cited. Colours indicate clusters of affinity: 1 , red; 2 , green; 3, dark blue; 4, yellow; 5, pink; 6 , light blue. Source: Web of Science (2016), Scopus (2016) and IJPM (2016).

Table 4. Classification of co-citation clusters based on the central theme.

\begin{tabular}{|c|c|c|c|}
\hline Cluster & $\begin{array}{c}\text { Central } \\
\text { Reference }^{*}\end{array}$ & Key Theme & Articles of the Sample ${ }^{* *}$ \\
\hline 1 & Nonaka, I. & $\begin{array}{l}\text { Knowledge } \\
\text { Management }\end{array}$ & $\begin{array}{c}\text { (Currie, 2003) } \\
\text { (Sexton \& Barrett, 2004) } \\
\text { (Fischer \& Eichenauer, 2006) } \\
\text { (Leopoulos et al., 2006) } \\
\text { (Lee \& Egbu, 2007) } \\
\text { (Owens, 2007) } \\
\text { (Huang et al., 2008) } \\
\text { (Sandhu \& Naaranoja, 2009) } \\
\text { (Hsu \& Fang, 2009) } \\
\text { (Blanc Alquier \& Lagasse Tignol, 2006) } \\
\text { (Tan et al., 2012) } \\
\text { (Karvonen et al., 2010) } \\
\text { (Hang Do et al., 2014) }\end{array}$ \\
\hline 2 & $\begin{array}{l}\text { Cusumano, } \\
\text { M. }\end{array}$ & $\begin{array}{l}\text { Portfolio Management } \\
\text { and IS Projects }\end{array}$ & $\begin{array}{c}\text { (Garg et al., 2010) } \\
(\text { Voss \& Kock, 2013) }\end{array}$ \\
\hline 3 & Land, M. J. & Production Management & $\begin{array}{l}\text { (Land \& Gaalman, 2009) } \\
\text { (Stevenson et al., 2011) }\end{array}$ \\
\hline 4 & Ahmed, S. & $\begin{array}{l}\text { Project Management in } \\
\text { the Construction } \\
\text { Industry }\end{array}$ & $\begin{array}{l}\text { (Chileshe \& Dzisi., 2012) } \\
\text { (Taggart et al., 2014) }\end{array}$ \\
\hline 5 & Love, P.E.D. & $\begin{array}{l}\text { IT Projects \& } \\
\text { Communication and } \\
\text { Supply Chain in the } \\
\text { Construction Industry }\end{array}$ & $\begin{array}{c}\text { (Chee \& Sloan, 2006) } \\
\text { (Dey et al., 2008) } \\
\text { (Pellicer et al., 2009) } \\
\text { (Ahuja et al., 2009a, 2009b, 2010a, 2010b) } \\
\text { (Taggart et al., 2014) }\end{array}$ \\
\hline 6 & Turner, J.R. & $\begin{array}{l}\text { General Practices of } \\
\text { Project Management in } \\
\text { SMEs }\end{array}$ & $\begin{array}{l}\text { (Forsman, 2008) } \\
\text { (Turner et al., 2009, 2010, 2012) } \\
\text { (Rostami et al., 2015) }\end{array}$ \\
\hline
\end{tabular}

*Based on the total link force calculated by VOSviewer; ** Cited the central reference. 
Cluster 1 related to knowledge management presented the central reference with the highest number of citations. The most cited work was "The knowledge-creating company" (Nonaka \& Takeuchi, 1995), whose main contribution was the definition of tacit and explicit knowledge. The study inspired articles about knowledge, risk management, obstacles to technology transfer and innovation in SMEs.

Cluster 5 had as main references the work of Peter Love who dealt with management in the construction industry, an example was the article "An exploratory study of information technology evaluation and benefits management of SMEs in the construction industry" (Love \& Irani, 2004, p.227). He contributed to articles approaching the adoption of IT, communication and supply chain tools in SMEs in the construction industry.

Another highlight was the researcher Rodney Turner (cluster 6). His major contribution in the area was a series of three articles that compared the practices adopted according to the SMEs' size and nature. These papers supported a project management approach more appropriate to the characteristics and needs of these companies (Turner et al., 2009, 2010, 2012).

\section{Content analysis}

The content analysis, based on the main papers, led to four thematic categories: Project Management Practices, Planning and Control Systems, Collaboration, and Knowledge Management. They are presented in Table 5. Figure 10 summarizes the discussion.

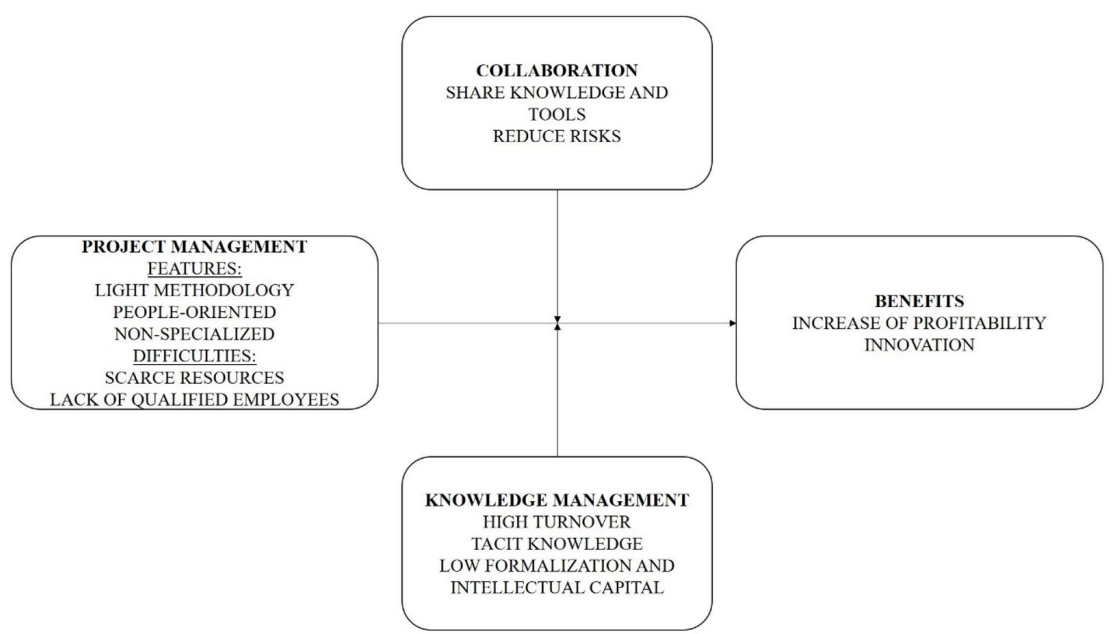

Figure 10. Discussion synthesis.

Table 5. Main themes approached in outliers and other relevant papers in the sample.

\begin{tabular}{cccc}
\hline Category & Topics & Articles & $\begin{array}{c}\text { Number of } \\
\text { articles }\end{array}$ \\
\hline Project Management & $\begin{array}{c}\text { Portfolio Management } \\
\text { Risk Management } \\
\text { Ecodesign }\end{array}$ & $\begin{array}{c}\text { (Meade \& Presley, 2002) } \\
\text { (Le Pochat et al., 2007) } \\
\text { (Turner et al., 2010) } \\
\text { (Voss \& Kock, 2013) }\end{array}$ & 5 \\
\hline
\end{tabular}


Table 5. Continued...

\begin{tabular}{|c|c|c|c|}
\hline Category & Topics & Articles & $\begin{array}{c}\text { Number of } \\
\text { articles }\end{array}$ \\
\hline & & $\begin{array}{l}\text { (Marcelino Sádaba et al., } \\
\text { 2014) }\end{array}$ & \\
\hline $\begin{array}{c}\text { Planning and Control } \\
\text { Systems }\end{array}$ & $\begin{array}{c}\text { ERP } \\
E-\text { procurement } \\
\text { WLC }\end{array}$ & $\begin{array}{c}\text { (Muscatello et al., 2003) } \\
\text { (Huin, 2004) } \\
\text { (Malhotra \& Temponi, 2010) } \\
\text { (Renna \& Argoneto, 2010) } \\
\text { (Stevenson et al., 2011) }\end{array}$ & 5 \\
\hline Collaboration & $\begin{array}{c}\text { Innovation } \\
\text { Research } \\
\text { Competitiveness }\end{array}$ & $\begin{array}{c}\text { (Davenport et al., 1998) } \\
\text { (Kernel, 2005) } \\
\text { (Okamuro, 2007) } \\
\text { (Bjerregaard, 2010) }\end{array}$ & 4 \\
\hline Knowledge management & $\begin{array}{l}\text { Tacit x Explicit } \\
\text { Knowledge } \\
\text { Innovation } \\
\text { Intellectual capital }\end{array}$ & $\begin{array}{c}\text { (Wong, 2005) } \\
(\text { Currie, 2003) } \\
\text { (Miranda et al., 2014) } \\
\text { (Sexton \& Barrett, 2004) } \\
\text { (Hsu \& Fang, 2009) } \\
\text { (Mannan et al., 2016) }\end{array}$ & 6 \\
\hline
\end{tabular}

\subsection{Project management practices}

SMEs implemented project management both to accomplish internal innovation and growth and to attend external customers' requirements (Turner et al., 2010, 2012). Businesses that used PM practices commonly reported increased profitability (Pollack \& Adler, 2016). However, very bureaucratic and formal methodologies, such as those proposed by PRINCE2, were not the most suitable, as best fit to large engineering and construction projects (Turner et al., 2010). SMEs required "light" versions of PM guides, aimed at non-specialized employees and involving informal communication. In addition, the practices required by smaller companies are different from those required by medium-sized enterprises (Turner et al., 2012).

SMEs applied PM practices in their operations to provide customized products to their customers, and to manage growth and innovation (Marcelino-Sádaba et al., 2014; Turner et al., 2010). However, few companies followed rigorous methodologies (Currie, 2003). Consequently, SMEs became less competitive and innovative than large companies (Hsu \& Fang, 2009; Wong, 2005).

Therefore, SMEs used and needed project management practices, however, two key factors impacted their success: limited resources and a lack of skilled employees (Le Pochat et al., 2007; Turner et al., 2010; Wong, 2005). Hence, there is a great challenge to be overcome: developing efficient and feasible PM approaches to be performed by SMEs. In this context, the literature has focused mainly on developing procedures, guides and models to assist in their successful implementation, as an example they presented models for risk management (Currie, 2003; Marcelino Sádaba et al., 2014; Renna \& Argoneto, 2010); resource management (Meade \& Presley, 2002); and ecodesign (Le Pochat et al., 2007). 


\subsection{Planning and control systems}

SMEs faced great challenges in entering global markets and becoming suppliers to large consumers (Malhotra \& Temponi, 2010). Mainly, in the manufacturing sector, they required production planning and control to deal with large companies (Huin, 2004). However, most enterprises were not used to plan, instead, they had produced only upon request of the customer (Renna \& Argoneto, 2010). To change this culture, SMEs adopted production planning tools already used by large companies, such as Enterprise Resource Planning (ERP) (Huin, 2004; Malhotra \& Temponi, 2010; Muscatello et al., 2003) and Workload Control (WLC) (Stevenson et al., 2011).

Hence, SMEs began to adopt systems that aid in the planning of production. Although these systems appeared as competitive advantages, their costly and complex implementation resulted in failures (Huin, 2004; Malhotra \& Temponi, 2010; Muscatello et al., 2003). Thus, the literature focused on identifying the success factors and developing suitable models for SMEs to implement ERP (Huin, 2004; Malhotra \& Temponi, 2010; Muscatello et al., 2003), WLC (Stevenson et al., 2011) and a new model for connecting commercial planning and negotiation through digital platforms (e-procurement) (Renna \& Argoneto, 2010).

\subsection{Collaboration}

Collaboration projects were means of sharing knowledge and tools. They were important, especially, for SMEs to overcome the lack of resources and to remain competitive. These due to the synergy effect, such as scale and scope gain, and risk reduction (Kernel, 2005; Okamuro, 2007). Many nations promoted cooperation between SMEs and research institutes and universities to encourage commercially productive relations through technology transfer (Bjerregaard, 2010; Davenport et al., 1998). Moreover, co-operation among SMEs could lead to common goals that benefit all companies in the same sector that would be difficult to achieve individually (Kernel, 2005).

Therefore, cooperation projects were important for SMEs to achieve strategic objectives, such as the development of a new product or sustainable development. The studies focused on the success factors for shared projects between SMEs and public research institutes (Bjerregaard, 2010; Davenport et al., 1998; Okamuro, 2007), and among SMEs and other business partners (Kernel, 2005; Okamuro, 2007).

Collaboration with other organizations can be a strategy for innovation in SMEs (Bjerregaard, 2010; Davenport et al., 1998; Kernel, 2005; Okamuro, 2007). It was a logical response to turbulent conditions and was a mean of transferring knowledge and tools (Kernel, 2005), technology (Davenport et al., 1998) and gain of scale and scope (Okamuro, 2007). However, there are also difficulties in managing these types of projects. For their success, they required efficient stakeholder management (Kernel, 2005), the establishment of trust between stakeholders, and a clear division of costs, responsibilities, and results (Davenport et al., 1998). Hence, PM practices were essential for SMEs to manage their innovation processes that allow them to be more competitive in the market. 


\subsection{Knowledge management in SMEs}

Project management also benefited innovation through knowledge management. Knowledge management is critical to business success (Wong, 2005). Most of the knowledge in SMEs was in the tacit form (Miranda et al., 2014), which was difficult to communicate and formalize (Sexton \& Barrett, 2004). Tacit knowledge is highly personal, non-standardized and consists especially of know-how (Currie, 2003). While explicit knowledge is formal, which makes it easy to share information and procedures (Currie, 2003). Furthermore, another difficulty in managing knowledge was the employee turnover, which led to information loose (Wong, 2005).

Successful implementation of knowledge management depends on the support of leadership, organizational culture, available technologies, and infrastructure, as well as strategic alignment and human resource management (Wong, 2005). In addition to inadequate knowledge management, other factors may have led to failures in innovation capacity, such as: the lack of investment in intellectual capital (human, relational and structural) (Hsu \& Fang, 2009), difficulties in introducing a new concept in the market, and to establish partnerships with organizations capable of producing innovation (Mannan et al., 2016).

\section{Discussion}

Supported by the results of the bibliometrics (keywords and co-citation networks), hot topics and content analysis of outliers, it was possible to map which themes are trends. The topics that were identified in all the analyses and their respective numbers of related publications were: Product Development (33), Information Technology (23), and Project Management (208). The themes of Planning (74), Knowledge Management (45) and Construction (42) were not only identified as a hot topic, however, they appeared in all other analyses.

Therefore, for researchers interested in SMEs, a trend is approaching the critical success factors and processes required for Project Management. A recommended source due to its prominence as a theoretical pillar (the network of co-citation) and as outlier are the articles of the group Turner, Ledwith \& Kelly. This group has conducted a series of studies to identify the best practices already used and the needs of European SMEs (Turner et al., 2009, 2010, 2012). These surveys could be replicated in other countries because they detail the methodology.

Another trend identified is the Knowledge Management. One of the theoretical pillars is the author Ikujiro Nonaka who popularized the classification of knowledge in tacit and explicit and demonstrated its importance for innovation (Nonaka \& Takeuchi, 1995). Knowledge management is recognized as a way to innovation, new product development and competitive advantage (Hang Do et al., 2014; Hsu \& Fang, 2009; Huang et al., 2008; Sexton \& Barrett, 2004; Wong, 2005). Furthermore, it is imperative for risk management, since it is necessary to create a history of risk and to share information to develop a risk assessment model (Currie, 2003; Leopoulos et al., 2006; Marcelino-Sádaba et al., 2014).

Moreover, the importance of the construction industry is highlighted. "Most construction companies are small and medium-sized enterprises (SMEs) that manage project-based and business-focused activities simultaneously" (Pellicer et al., 2009, p. 4). The construction sector experienced transformations to absorb tools developed in the manufacturing to become more productive and reduce costs and waste 
(Dainty et al., 2001; Taggart et al., 2014). This evolution was also drawn in the keyword network since terms related to industry, production, and planning (such as ERP) preceded those related to construction. Therefore, there was a transfer of knowledge and tools from the manufacturing to the construction. As construction was not indicated as a hot topic, other sectors should dominate research in the area, such as technology companies (startups) and services, because SMEs dominate these sectors (OECD, 2016).

Regarding the Brazilian scenario, the sample had only four articles and, curiously, all dealt with technology-based SMEs. They are recent publications, after 2009, which supports the previous hypothesis that research on technology companies is a trend. Brazilian SMEs presented high levels of informality and a lack of knowledge and risk management (Juca et al., 2010; Miranda et al., 2014). The researches were performed in a qualitative way, demonstrating that the area is still in development. The themes were: project management maturity (Juca et al., 2010); risk management (Miranda et al., 2014); PMO implementation (Richter, 2009); and the development of software that could help SMEs to improve their practices (Pereira et al., 2013).

Therefore, quantitative studies are needed to have a diagnosis of project management practices in SMEs in Brazil. Turner, Ledwith \& Kelly publications can serve as a basis. Moreover, none addressed critical success factors, so identifying them for the national context would also be a relevant contribution. Although all four articles approached with technological SMEs, they focused on the development of software. Thus, studies in other sectors would be relevant due to their essential role in the social and economic development of the country through innovation (Juca et al., 2010). One example would be to study the relationship of cooperation between SMEs and public research institutes and universities in biotechnology projects, as they result in products of high added value that directly impact the population.

\section{Conclusions}

This article proposed to answer the RQ: What are the challenges and benefits of project management for SMEs?

The survey of 235 publications on Project Management in SMEs from the Web of Science and Scopus databases and the International Journal of Project Management allowed us to answer the research question, contributing to the literature in presenting the challenges, characteristics, and benefits of project management in SMEs.

Project management in SMEs is characterized by their requirement for lighter PM methodologies, associated with the flexibility, few resources, people-oriented, and for non-specialized employees. In addition, for a good PM, SMEs should seek collaboration with external stakeholders to mitigate resource shortages, looking for synergies. The benefits indicated increased profitability and innovation in SMEs. The results demonstrated that the main challenges involve the lack of resources and qualified personnel and high turnover.

Four thematic categories appeared to be most promising for future work: Project Management Practices; Planning and Control Systems; Collaboration; and Knowledge Management.

Through bibliometric and content analysis, it was observed that there was a transition of knowledge and practices between sectors. Initially, the studies focused on the manufacturing industry as small and medium suppliers of large companies needed to adapt to project management practices to become more competitive and serve 
global markets. The prominence in the area was the studies on implementing ERP (Enterprise Resource Planning) systems. These practices were adopted by the construction industry, also formed predominantly by SMEs, to become more productive. Finally, through the analysis of hot topics and the most recent articles, we noticed that the focus is becoming technology-based companies.

Finally, we suggested a quantitative study to evaluate the extent of the use of good management practices and to identify the critical success factors for the projects in Brazil. In addition, it was encouraged to expand research on technology-based SMEs since innovation is the way to social and economic development (Juca et al., 2010). Moreover, it would be interesting to approach partnerships with universities, because collaboration helps to optimize the use of resources and results in innovation through technology transfer.

The limitations of this article were associated with the methodology. Interesting articles may have been excluded from sampling, although the bases chosen are very inclusive. Additionally, important information may have been lost during data analysis as it is subject to human error. However, we believe that statistical and bibliometric analyses help to soften biased interpretations.

\section{Acknowledgements}

This work was supported by research grants from Brazilian Federal Agency for Support and Evaluation of Graduate Education (No. 1626676) and the São Paulo Research Foundation (FAPESP, Grant No. 2017/25065-9).

\section{References}

Ahuja, V., Yang, J., \& Shankar, R. (2009a). Perceptions affecting ict adoption for building project management in the Indian construction industry. International Journal of Construction Management, 10(2), 1-18. http://dx.doi.org/10.1080/15623599.2010.10773141.

Ahuja, V., Yang, J., \& Shankar, R. (2009b). IT-enhanced communication protocols for building project management. Engineering, Construction, and Architectural Management, 17(2), 159-179. http://dx.doi.org/10.1108/09699981011024678.

Ahuja, V., Yang, J., Skitmore, M., \& Shankar, R. (2010a). An empirical test of causal relationships of factors affecting ICT adoption for building project management: an Indian SME case study. Construction Innovation, 10(2), 164-180. http://dx.doi.org/10.1108/14714171011037174.

Ahuja, V., Yang, J., \& Shankar, R. (2010b). Benchmarking framework to measure extent of ICT adoption for building project management. Journal of Construction Engineering and Management, 136(5), 538-545. http://dx.doi.org/10.1061/(ASCE)CO.1943-7862.0000155.

Banks, M. G. (2006). An extension of the Hirsch index: indexing scientific topics and compounds. Scientometrics, 69(1), 161-168. http://dx.doi.org/10.1007/s11192-006-0146-5.

Bazeley, P., \& Jackson, K. (2013). Qualitative data analysis with NVivo. California: Sage Publications Limited.

Blanc Alquier, A. M., \& Lagasse Tignol, M. H. (2006). Risk management in small- and mediumsized enterprises. Production Planning and Control, 17(3), 273-282. http://dx.doi.org/10.1080/09537280500285334 
Bjerregaard, T. (2010). Industry and academia in convergence: micro-institutional dimensions of R\&D collaboration. Technovation, 30(2), 100-108. http://dx.doi.org/10.1016/j.technovation.2009.11.002.

Brasil. (2006). Lei Complementar no 123, de 14 de dezembro DE 2006: estatuto nacional da Microempresa e da Empresa de Pequeno Porte. Brasília, DF: Diário Oficial da República Federativa do Brasil.

Carvalho, M. M., Fleury, A., \& Lopes, A. P. (2013a). An overview of the literature on technology roadmapping (TRM): contributions and trends. Technological Forecasting and Social Change, 80(7), 1418-1437. http://dx.doi.org/10.1016/j.techfore.2012.11.008.

Carvalho, M., Lopes, P., \& Marzagão, D. (2013b). Gestão de portfólio de projetos: contribuições e tendências da literatura. Gestão \& Produção, 20(2), 433-454. http://dx.doi.org/10.1590/S0104-530X2013000200013.

Chee, H. W., \& Sloan, B. (2006). An empirical survey of the UK construction smes' eprocurement readiness from the e-legal aspects. Journal of Construction Research, 7(81), 81-97. http://dx.doi.org/10.1142/S160994510600044X

Chileshe, N. \& Dzisi, E. (2012). Benefits and barriers of construction health and safety management (HSM): Perceptions of practitioners within design organisations, Journal of Engineering, Design and Technology, 10 (2) 276-298. http://dx.doi.org/10.1108/17260531211241220.

Currie, W. L. (2003). A knowledge-based risk assessment framework for evaluating webenabled application outsourcing projects. International Journal of Project Management, 21(3), 207-217. http://dx.doi.org/10.1016/S0263-7863(02)00095-9.

Dainty, A. R. J., Millett, S. J., \& Briscoe, G. H. (2001). New perspectives on construction supply chain integration. Supply Chain Management, 6(4), 73-163. http://dx.doi.org/10.1108/13598540110402700.

Dangayach, G. S., \& Deshmukh, S. G. (2005). Advanced manufacturing technology implementation: evidence from Indian small and medium enterprises (SMEs). Journal of Manufacturing Technology Management, 16(5), 483-496. http://dx.doi.org/10.1108/17410380510600473.

Davenport, S., Davies, J., \& Grimes, C. (1998). Collaborative research programmes: building trust from difference. Technovation, 19(1), 31-40. http://dx.doi.org/10.1016/S01664972(98)00083-2.

Dean, P. R., Xue, D., \& Tu, Y. L. (2009). Prediction of manufacturing resource requirements from customer demands in mass-customization production. International Journal of Production Research, 47(5), 1245-1268. http://dx.doi.org/10.1080/00207540701557197.

Dey, W. B., Ho, W., Charoenngam, C., \& Deewong, W. (2008). Relationship characteristics within the supply chain of small and medium-sized construction enterprises in Thailand. International Journal of Manufacturing Technology and Management, 15(1), 102-118. http://dx.doi.org/10.1504/IJMTM.2008.018242

Dyerson, R., Spinelli, R., \& Harindranath, G. (2016). Revisiting IT readiness: an approach for small firms. Industrial Management \& Data Systems, 116, 546-563. http://10.1108/IMDS05-2015-0204.

Egbetokun, A. A., Olamade, O. O., Siyanbola, W. O., Adeniyi, A. A., \& Irefin, I. A. (2009). Innovation in Nigerian small and medium enterprises: types and impact. Journal of Electronic Commerce in Organizations, 7(4), 40-51. http://dx.doi.org/10.4018/jeco.2009100104.

Feldmann, P. A. (2011, Fevereiro). A pequena empresa como fonte de desenvolvimento. Valor Econômico.

Fischer, T.V., \& Eichenauer, D. (2006). The implementation of knowledge management at Trevira R\&D - From the conception to a practical guide. VDI-Berichte, 61-80. 
Fleury, A. L., Stabile, H., \& Carvalho, M. M. (2016). An overview of the literature on design thinking : trends and contributions. International Journal of Engineering Education, 32(4), 1704-1718.

Forsman, H. (2008). Business development success in SMEs: a case study approach. Journal of Small Business and Enterprise Development, 15(3), 606-622. http://dx.doi.org/10.1108/14626000810892382.

Garg, A. S., Goyal, A. A., \& Lather, D. P. B. (2010). The influence of the best practices of information system development on software SMEs: a research scope. International Journal of Business Information Systems, 5(3), 268-290. http://dx.doi.org/10.1504/IJBIS.2010.03193.

Glänzel, W. (2013). High-end performance or outlier? Evaluating the tail of scientometric distributions. Scientometrics, 97(1), 13-23. http://dx.doi.org/10.1007/s11192-013-1022-8

Hang Do, T., Mazzarol, T., Volery, T., \& Reboud, S. (2014). Predicting anticipated rent from innovation commercialisation in SMEs. European Journal of Innovation Management, 17(2), 183-208. http://dx.doi.org/10.1108/EJIM-12-2012-0113.

Hsu, Y.-H., \& Fang, W. (2009). Intellectual capital and new product development performance: the mediating role of organizational learning capability. Technological Forecasting and Social Change, 76(5), 664-677. http://dx.doi.org/10.1016/j.techfore.2008.03.012.

Huang, C.-M., Chang, H.-C., \& Henderson, S. (2008). Knowledge transfer barriers between research and development and marketing groups within taiwanesesmall- and mediumsized enterprise high-technology new product development teams. Human Factors and Ergonomics in Manufacturing, 18(6), 621-657. http://dx.doi.org/10.1002/hfm.20130.

Huin, S. F. (2004). Managing deployment of ERP systems in SMEs using multi-agents. International Journal of Project Management, 22(6), 511-517. http://dx.doi.org/10.1016/j.ijproman.2003.12.005.

Hwang, I. P., \& Ward, A. E. (2001). How a developing country supports innovation in its SMEs. Engineering Management Journal, 11(1), 25-33.

IJPM - International Journal of Project Management. (2016). Retrieved in 2016, September 30, from https://www.journals.elsevier.com/international-journal-of-project-management.

Iritani, D. R., Morioka, S. N., Carvalho, M. M., \& Ometto, A. R. (2015). Análise sobre os conceitos e práticas de Gestão por Processos: revisão sistemática e bibliometria. Gestão \& Produção, 22(1), 164-180. http://dx.doi.org/10.1590/0104-530X814-13.

Jacobsson, M., \& Linderoth, H. C. (2012). User perceptions of ICT impacts in Swedish construction companies:'it's fine, just as it is'. Construction Management and Economics, 30(5), 339-357. http://dx.doi.org/10.1080/01446193.2012.672757.

Juca, A. S., Jr., Conforto, E. C., \& Amaral, D. C. (2010). Maturidade em gestão de projetos em pequenas empresas desenvolvedoras de software do Polo de Alta Tecnologia de São Carlos. Gestão \& Produção, 17(1), 181-194. https://doi.org/10.1590/S0104$530 \times 2010000100014$.

Karvonen, M., Salkari, I., \& Ollus, I. (2010). Increasing collaboration preparedness and performance through VO inheritance. International Journal of Services and Operations Management, 6(3), 293-312. http://dx.doi.org/10.1504/IJSOM.2010.031955

Kernel, P. (2005). Creating and implementing a model for sustainable development in tourism enterprises. Journal of Cleaner Production, 13(2), 151-164. http://dx.doi.org/10.1016/j.jclepro.2003.12.023.

Land, G. J. C., \& Gaalman, M. J. (2009). Production planning and control in SMEs: time for change. Production Planning and Control, 20(7), 548-558.

http://dx.doi.org/10.1080/09537280903034230. 
Le Pochat, S., Bertoluci, G., \& Froelich, D. (2007). Integrating ecodesign by conducting changes in SMEs. Journal of Cleaner Production, 15(7), 671-680.

http://dx.doi.org/10.1016/j.jclepro.2006.01.004.

Lee, C. C. T., \& Egbu, C. O. (2007). Information technology tools for capturing and communicating learning and experiences in construction smes in developed and developing countires. Electronic Journal of Information Technology in Construction, 12(2007), 167-180.

Leopoulos, V. N., Kirytopoulos, K. A., \& Malandrakis, C. (2006). Risk management for SMEs: tools to use and how. Production Planning \& Control, 17, 322-332.

Lin, Y.-C. (2010). Development of web-based teams management system in construction. World Academy of Science, Engineering and Technology, 65, 1105-1110.

Love, P. E. D., \& Irani, Z. (2004). An exploratory study of information technology evaluation and benefits management practices of SMEs in the construction industry. Information \& Management, 42(1), 227-242. https://doi.org/10.1016/j.im.2003.12.011.

Malhotra, R., \& Temponi, C. (2010). Critical decisions for ERP integration: small business issues. International Journal of Information Management, 30(1), 28-37. http://dx.doi.org/10.1016/j.ijinfomgt.2009.03.001.

Mannan, B., Khurana, S., Haleem, A., \& Nisar, T. (2016). Modeling of critical factors for integrating sustainability with innovation for Indian small- and medium-scale manufacturing enterprises: an ISM and MICMAC approach. Cogent Business \& Management, 3(1), 15. http://dx.doi.org/10.1080/23311975.2016.1140318.

Maravelakis, E., Bilalis, N., Antoniadis, A., Jones, K. A., \& Moustakis, V. (2006). Measuring and benchmarking the innovativeness of SMEs: a three-dimensional fuzzy logic approach. Production Planning and Control, 17(3), 283-292. http://dx.doi.org/10.1080/09537280500285532.

Marcelino Sádaba, S., Pérez-Ezcurdia, A., Echeverría-Lazcano, A. M., \& Benito Amurrio, M. (2016). Definition of innovation projects in small firms: a Spanish study. $R \& D$ Management, 46(1), 36-48. http://dx.doi.org/10.1111/radm.12109.

Marcelino-Sádaba, S., Pérez-Ezcurdia, A., Echeverría Lazcano, A. M., \& Villanueva, P. (2014). Project risk management methodology for small firms. International Journal of Project Management, 32(2), 327-340. http://dx.doi.org/10.1016/j.ijproman.2013.05.009.

Meade, L. M., \& Presley, A. (2002). R\&D project selection using the analytic network process. IEEE Transactions on Engineering Management, 21(2), 59-66. http://dx.doi.org/10.1109/17.985748.

Minitab. (2010). Minitab 17 Statistical Software. Retrieved in 2017, January 30, from www.minitab.com

Miranda, S., Eduardo, C., Antonio, V., Salomon, P., Francisco, A., Elizabeth, B., \& Sotomonte, P. (2014). Science direct Risk management in software projects through knowledge management techniques: cases in Brazilian incubated technology-based firms. Journal of Pakistan Medical Association, 32(1), 125-138.

Mohammadjafari, M., Ahmed, S., \& Dawal, S. Z. (2011). A review of literature on reducing time and cost of new product in smes through project management by e-collaboration. Proceedings of the 2011 International Conference on Industrial Engineering and Operations Management Kuala Lumpur, 125-130.

Moreau, E. M.-F. (2016). Project management for a plant implementation: success or failure? Journal of Modern Project Management, 3(3), 46-55.

Muller, P., Caliandro, C., Peycheva, V., Gagliardi, D., Marzocchi, C., Ramlogan, R., \& Cox, D. (2015). Annual Report on European SMEs 2014/2015. Bruxelas: European Union. http://dx.doi.org/10.2873/886211. 
Muscatello, J. R., Small, M. H., \& Chen, I. J. (2003). Implementing enterprise resource planning (ERP) systems in small and midsize manufacturing firms. International Journal of Operations \& Production Management, 23(7-8), 850-871. http://dx.doi.org/10.1108/01443570310486329.

Nonaka, I., \& Takeuchi, H. (1995). The knowledge-creating company: how japanese companies create the dynamics of innovation. Norman, Oklahoma: O. U. Press.

Okamuro, H. (2007). Determinants of successful R\&D cooperation in Japanese small businesses: the impact of organizational and contractual characteristics. Research Policy, 36(10), 1529-1544. http://dx.doi.org/10.1016/j.respol.2006.12.008.

Organisation for Economic Co-operation and Development - OECD. (2016). Entrepreneurship at a Glance 2016. Retrieved in 2017, January 30, from http://www.oecd.org/std/businessstats/entrepreneurship-at-a-glance-22266941.htm

Owens, J. D. (2007). Why do some UK SMEs still find the implementation of a new product development process problematical?: an exploratory investigation. Management Decision, 45(2), 235-251.

Pellicer, E., Pellicer, T. M., \& Catala, J. (2009). An integrated control system for SMEs in the construction industry. Revista de la Construcción, 8(2), 4-17.

Pereira, A. M., Gonçalves, R. Q., von Wangenheim, C. G., \& Buglione, L. (2013). Comparison of open source tools for project management. International Journal of Software Engineering and Knowledge Engineering, 23(2), 189-209. https://doi.org/10.1142/S0218194013500046.

Pollack, J., \& Adler, D. (2016). Skills that improve profitability: the relationship between project management, IT skills, and small to medium enterprise profitability. International Journal of Project Management, 34(5), 831-838. http://dx.doi.org/10.1016/j.ijproman.2016.03.004.

Pons, D., \& Haefele, S. (2016). Team Interactions for Successful Project Management in Small and Medium-Sized Enterprises. International Journal of Information Technology Project Management, 7(2), 17-43. http://dx.doi.org/10.4018/IJITPM.2016040102.

Proverbs, D., Holt, G., \& Olomolaiye, P. (1999). The management of labour on high rise construction projects: an international investigation. International Journal of Project Management, 17(3), 195-204. http://dx.doi.org/10.1016/S0263-7863(98)00025-8.

QSR International Pty Ltd. (2012). NVivo qualitative data analysis software. Retrieved in 2017, January 30, from www.qsrinternational.com

Renna, P., \& Argoneto, P. (2010). Production planning and automated negotiation for SMEs: an agent based e-procurement application. International Journal of Production Economics, 127(1), 73-84. http://dx.doi.org/10.1016/j.ijpe.2010.04.035.

Richter, E. H. (2009). Rompendo obstáculos para a implantação de escritório de projetos em empresa de base tecnológica. Gestão \& Produção, 16(3), 435-449.

Rostami, C., Sommerville, A., Wong, J., \& Lee, I. L. (2015). Risk management implementation in small and medium enterprises in the UK construction industry. Engineering, Construction, and Architectural Management, 22(1), 91-107. http://dx.doi.org/10.1108/ECAM-04-2014-0057

Sage, D., Dainty, A., \& Brookes, N. (2010). A consideration of reflexive practice within the critical projects movement. International Journal of Project Management, 28(6), 539-546. http://dx.doi.org/10.1016/j.jproman.2009.10.002.

Sampaio, R., \& Mancini, M. (2007). Estudos de revisão sistemática: um guia para síntese criteriosa da evidência científica. Brazilian Journal of Physical Therapy, 11(1), 83-89. http://dx.doi.org/10.1590/S1413-35552007000100013.

Sandhu, M., \& Naaranoja, M. A. (2009). Knowledge management practices in project-based organisations. International Journal of Business Excellence., 2(2), 140-156.

Scopus. (2016). Retrieved in 2016, September 30, from www.scopus.com. 
Serviço Brasileiro de Apoio às Micro e Pequenas Empresas - SEBRAE. (2014). Participação das micro e pequenas empresas na economia brasileira. Brasília: SEBRAE.

Sexton, M., \& Barrett, P. (2004). The role of technology transfer in innovation within small construction firms. Engineering, Construction, and Architectural Management, 11(5), 342348. http://dx.doi.org/10.1108/09699980410558539.

Small, H. (1973). Co-citation in the scientific literature: a new measure of the relationship between two documents. Journal of the American Society for Information Science, 24(4), 265-269. http://dx.doi.org/10.1002/asi.4630240406.

Stevenson, M., Huang, Y., Hendry, L. C., \& Soepenberg, E. (2011). The theory and practice of workload control: A research agenda and implementation strategy. International Journal of Production Economics, 131(2), 689-700. http://dx.doi.org/10.1016/j.jpe.2011.02.018.

Taggart, M., Koskela, L., \& Rooke, J. (2014). The role of the supply chain in the elimination and reduction of construction rework and defects: an action research approach. Construction Management and Economics, 32(7-8), 1-14. http://dx.doi.org/10.1080/01446193.2014.904965.

Tan, H. C., Carrillo, P. M., \& Anumba, C. J. (2012). Case study of knowledge management implementation in a medium-sized construction sector firm. Journal of Management Engineering, 28(3), 338-347. http://dx.doi.org/10.1061/(ASCE)ME.1943-5479.0000109

Turner, R., Ledwith, A., \& Kelly, J. (2009). Project Management in small to medium-sized enterprises: a comparison between firms by size and industry. International Journal of Managing Projects in Business, 2(2), 282-296. http://dx.doi.org/10.1108/17538370910949301.

Turner, R., Ledwith, A., \& Kelly, J. (2010). Project management in small to medium-sized enterprises: matching processes to the nature of the firm. International Journal of Project Management, 28(8), 744-755. http://dx.doi.org/10.1016/j.jproman.2010.06.005.

Turner, R., Ledwith, A., \& Kelly, J. (2012). Project management in small to medium-sized enterprises Tailoring the practices to the size of company. Management Decision, 50(2), 942-957. http://dx.doi.org/10.1108/00251741211227627.

van Eck, N. J., \& Waltman, L. (2010). Software survey: VOSviewer, a computer program for bibliometric mapping. Scientometrics. Retrieved in 2017, January 30, from www.vosviewer.com

Von Ahsen, A., \& Heesen, M. (2009). Innovation portfolio management: a framework for SMEs in the automotive industry. International Journal of Technology Intelligence and Planning, 5(2), 138. http://dx.doi.org/10.1504/IJTIP.2009.024175.

Voss, M., \& Kock, A. (2013). Impact of relationship value on project portfolio success investigating the moderating effects of portfolio characteristics and external turbulence. International Journal of Project Management, 31(6), 847-861. http://dx.doi.org/10.1016/j.ijproman.2012.11.005.

Watanuki, H. M., Nadae, J., Carvalho, M. M., \& Moraes, R. O. (2014). Gestão de projetos internacionais: um estudo bibliométrico. Gestão \& Produção, 21(3), 660-675. http://dx.doi.org/10.1590/0104-530X394.

Web of Science. (2016). Retrieved in 2016, September 30, from www.webofknowledge.com.

Wong, K. Y. (2005). Critical success factors for implementing knowledge management in small and medium enterprises. Industrial Management \& Data Systems, 105(3), 261-279. http://dx.doi.org/10.1108/02635570510590101.

Zafeiropoulos, I., Metaxiotis, K., \& Askounis, D. (2005). Dynamic risk management system for the modeling, optimal adaptation and implementation of an ERP system. Information Management \& Computer Security, 13(3), 212-234. http://dx.doi.org/10.1108/09685220510602031. 